\title{
Quality of the forage apparently consumed by beef calves in natural grassland under fertilization and oversown with cool season forage species $^{1}$
}

\section{Denise Adelaide Gomes Elejalde ${ }^{2}$, Carlos Nabinger ${ }^{2}$, Mónica Graciela Cadenazzi Pascual ${ }^{3}$, Eduardo Tonet Ferreira ${ }^{2}$, Regis Luis Missio ${ }^{4}$, Taise Robinson Kunrath ${ }^{2}$, Thais Devincenzi², Raquel Rolim Cardoso 5}

\footnotetext{
${ }^{1}$ Sponsored by CNPq (Edital MCT/CNPq 15/2007) and Agropecuária Cantagalo.

2 Programa de Pós-Graduação em Zootecnia, Faculdade de Agronomia, Universidade Federal do Rio Grande do Sul, Brasil.

${ }^{3}$ Faculdad de Agronomía, Universidad de La República Del Uruguay.

${ }^{4}$ Programa de Pós-Graduação em Zootecnia, Universidade Estadual de São Paulo - Jaboticabal.

${ }^{5}$ Universidade Federal do Rio Grande do Sul. Scholar from DTI/CNPq.
}

\begin{abstract}
The objective of this study was to evaluate the chemical composition of the forage apparently consumed by steers in a natural grassland on region of Campanha, in Rio Grande do Sul, Brazil, subjected or not to different inputs: NP natural pasture without inputs; FNP - fertilized natural pasture and INP - improved natural grassland with fertilization and over-seeded with cultivated winter species. Three Angus steers testers and a variable number of regulator animals per experimental unit were utilized in order to maintain $13 \mathrm{~kg}$ of DM/100 kg of live weight (LW) as forage allowance. One time at each season, hand plucking samples were performed along the daily grazing time simulating forage harvested by the animals. The collected samples after drying and grind were submitted to chemical analysis to determine the forage quality. Except in winter and spring, the values of neutral detergent fiber were higher than the critical value of $550 \mathrm{~g} / \mathrm{kg}$ of DM, which could limit forage intake, demonstrating that the values of forage on offer provided $(15.6 ; 13.7 ; 13.5 ; 15.8 \mathrm{~kg}$ of DM/100 kg of LW/day in summer, autumn, winter and spring, respectively) were not restrictive to intake. The oversowing of winter cultivated species or fertilization positively alter the degradable fiber content. The seasons had marked influence on the chemical composition of forage apparently consumed; positively increasing some fractions of forage chemical composition in the seasons in which native or cultivated winter species increased their participation. The forage chemical composition is the determining factor in animal performance in natural pasture.
\end{abstract}

Key Words: average daily weight gain, gas in vitro digestibility, neutral detergent fiber corrected for ash and protein, total digestible nutrients

\section{Introduction}

Pastures and especially natural grasslands are the most economic source of nutrients to feed ruminants because of their ability to digest fibrous feeds. On the natural grasslands from Pampa Biome, forage quality can be limited by their botanical composition but specially by the interaction between species composition and season of the year (Silveira et al., 2005). A few studies have been conducted in order to measure the seasonal quality of natural pastures from this biome and most sampling methods are not representative of what was effectively collected by the animal. Seasonal fluctuation in forage quality from pastures results both from morphological alterations of plants as function of its phenological evolution and from seasonal replacement of flora species, as occurs in some natural grasslands. This flora can be substantially altered by grazing pressure, soil fertility or introduction (by direct drilling) of exotic species (Nabinger et al., 2009).

The ability of the animal to meet its nutritional needs depends mainly on the energy and protein content of its diet that can be used by rumen micro flora or escape from fermentation in this compartment to be used in other compartments of the intestinal tract. Livestock farming is directly responsible for the quantity and quality of feed consumed (Minson, 1982). Knowledge of the quantity, composition and quality of forage available and the forage selected by the animals is the starting point for the structuring of sustainable production systems.

Thus, the knowledge of quality and production indicators of natural pasture is fundamental to building simulation models as a tool to aid the development of technological alternatives to animal production systems on pasture in southern Brazil. 
This study was conducted to evaluate the chemical composition throughout the seasons, of the forage apparently consumed by finishing steers in natural pasture, typical of deep black soils of the "Campanha" region of Rio Grande do Sul, Brazil, subjected or not to fertilization and overseeding of winter cultivated species. Relations between the chemical composition of the forage apparently consumed and the performance of the grazing animals were also analyzed.

\section{Material and Methods}

The assay was conducted on the Cantagalo Farm, in the municipality of Quaraí, physiographic region of the Campanha in Rio Grande do Sul, Brazil (30¹6'12"S, $\left.55^{\circ} 50^{\prime} 51^{\prime \prime} \mathrm{W}\right)$, between January 1st and October 29, 2008 (293 days). The soil of the area is classified as Orthic Vertisol Ebony Chernosol (Embrapa, 2006), whose analysis showed the following characteristics: $\mathrm{pH}$ 5.5, 7.1\% organic matter, $5.8 \mathrm{mg} / \mathrm{dm}^{3}$ of phosphorus, $104 \mathrm{mg} / \mathrm{dm}^{3}$ potassium, $81.6 \%$ of base saturation and absence of $\mathrm{Al}$ (Table 1).

According to Rambo (1956) grasslands in this region are composed mainly of the families Poaceae, Compositae, and Fabaceae, but the high variability of soils results in great diversity of phyto physiognomies with quite distinct local flora. According to the the Köeppen classification, the regional climate corresponds to a mesothermic and subtropical type, Cfa 2 class (Table 1 ).

Depending on the predominant topography (hill top, slope and lowland), the experimental area was divided in three blocks. In each block, the following treatments were applied: natural pasture (control), fertilized natural pasture and natural pasture improved with fertilization and oversowing of cultivate winter forage species. The experimental units measured between 3.5 ha (improved natural pasture) to 8.1 ha (natural pasture), totaling 49 ha.

The application of inputs occurred about nine months before the start of observations of this study. On April 4, 2007, the treatment of fertilized natural pasture was top dressed with $200 \mathrm{~kg} / \mathrm{ha}$ diammonium phosphate (18-45-00) and in September, $200 \mathrm{~kg} / \mathrm{ha}$ of urea (45-00-00) were applied. Treatment improved natural pasture received the same levels of fertilization in the same periods that the fertilized natural pasture treatment, as well as the sod seeding of winter species along with the first fertilization. The species used were ryegrass (Lolium multiflorum Lam), birdsfoot trefoil (Lotus corniculatus cv. San Gabriel) and white clover (Trifolium repens cv. Lucero), at seed rates of $30 ; 8$ and $3 \mathrm{~kg} / \mathrm{ha}$, respectively. After fertilization and seeding, all experimental units remained deferred for 89 days (until 07/07/07), to allow the proper establishment of introduced species. In 2008, the experimental units were mowed (between February 15 and 27), and fertilized in April with $100 \mathrm{~kg}$ diammonium phosphate /ha, totaling $144 \mathrm{~kg} / \mathrm{ha}$ of $\mathrm{N}$ and $135 \mathrm{~kg} / \mathrm{ha}$ of $\mathrm{P}_{2} \mathrm{O}_{5}$. At same time, ryegrass seeds were broadcast at a rate of $20 \mathrm{~kg} / \mathrm{ha}$ and all experimental area was deferred by 75 days (May 03 to July 07).

The animals remained under continuous stocking with variable stocking rate to maintain the daily herbage allowance of about $13 \mathrm{~kg}$ DM/100 kg of body weight (BW) as recommended by Maraschin (2001). In the first year, Aberdeen Angus castrated calves, aged nine months and with initial average body weight $233 \mathrm{~kg}$ were used. The same animals remained in the experimental area in the second year when the observations concerned to this study were made. Each experimental unit received four tester animals and a variable number of regulators, according to Mott \& Lucas (1952).

The forage mass ( $\mathrm{kg} \mathrm{DM} / \mathrm{ha}$ ) was evaluated every 28 days, using the technique of "double sampling” (Haydock \& Shaw, 1975). The sward height (cm) was measured with a sward stick as Barthram (1985). The forage accumulation rate (kg DM/ha/day) was estimated according to Klingman et al. (1943), using three cages of grazing exclusion per experimental unit. To describe de pasture characteristics, the data used were those collected in the period preceding the grazing simulating samples.

Trained assessors performed the simulation of grazing by observing the feeding behavior of animals during the day, following the testers animals and manually collecting species and plant parts similar to those consumed by them, according to Moraes et al. (2005). Four evaluations were conducted to simulate grazing, one in each season (January 10, April 19, August 25 and October 29, 2008, for

Table 1 - Daily temperatures recorded in the region during forage sampling in each season

\begin{tabular}{|c|c|c|c|c|}
\hline \multirow[t]{2}{*}{ Registered temperatures $\left({ }^{\circ} \mathrm{C}\right)$} & \multicolumn{4}{|c|}{ Season } \\
\hline & Summer $(01 / 10)$ & Fall $(04 / 19)$ & Winter $(08 / 15)$ & Spring $(10 / 29)$ \\
\hline Maximal & 37.8 & 28.9 & 18.9 & 26.9 \\
\hline Average & 29.1 & 22.3 & 15.7 & 22.3 \\
\hline
\end{tabular}

Source: Meteorological station of INMET (Instituto Nacional de Meteorologia) at Quaraí - RS, Brazil. 
summer, fall, winter and spring, respectively). Samples were collected with about $0.3 \mathrm{~kg}$ of green matter that was pre-dried in a forced-ventilation oven at $55^{\circ} \mathrm{C}$ for 72 hours, ground in a Wiley type mill with sieves of $1 \mathrm{~mm}$ in diameter, packed in plastic containers and properly identified for further chemical analysis.

The samples were analyzed at the Laboratory of Animal Nutrition, UNESP - Jaboticabal for determination of dry matter (DM), mineral matter (MM), crude protein (CP) and ether extract (EE), according to the AOAC (1995). The organic matter $(\mathrm{OM})$ of the samples was obtained by subtracting MM from the DM. Analysis of neutral (NDF) and acid (ADF) detergent fiber were done in an autoclave according to Pell \& Schofield (1993), and acid detergent lignin according to Van Soest et al. (1991). The NDF was corrected for ash and protein (NDFap) to calculate TDN of the diet. In the residue obtained from the analysis of NDF and ADF, the levels of neutral (NDIP) and acid (ADIP) detergent insoluble protein were analyzed as recommended by Licitra et al. (1996).

The content of total digestible nutrients (TDN) was estimated according to summative equations proposed by Detmann et al. (2008a) for growing and finishing cattle, with the addition of bicompartimental sub-model (Detmann et al., 2008b) to estimate the fraction of dietary protein apparently digestible CP (crude protein from cellular content and CP associated with the cell wall). Non-fibrous carbohydrates (NFC) were calculated by the formula $\mathrm{NFC}=100-(\% \mathrm{CP}+\% \mathrm{EE}+\% \mathrm{MM}+\% \mathrm{NDFap})$.

The organic matter in vitro digestibility (OMIVD) was calculated trough the technique of in vitro gas production, according to the methodology of Theodorou et al. (1994) modified by Maurício et al. (1999). There were two rounds of incubation with two blanks and three replicates per treatment in each round. The incubation period was 144 hours and readings of pressure and fluid sampling were done at 2, 4, 6, 8, 10, 12, 24, 26, 28, 30, 32, 36, 48, 52, 56 , 60, 72, 76, 80, 84, 96, 100, 104, 108, 120, 124, 128, 132, 144 hours after incubation.

The experimental design was a randomized blocks with three treatments and three replications. The data were subjected to analysis of normality and were adjusted whenever necessary by $\log ^{2}$. Once the assumptions of normality and homogeneity of variances were satisfied, data were subjected to analysis of variance and Pearson correlation. The analysis of variance was done through the MIXED procedure (Littel et al., 1996) of the statistical software SAS (Statistical Analysis System, version 8.2), using the season as a repeated measure in time at $5 \%$ significance level. Means were compared by Pdiff (5\% significance level). Multiple regressions were performed by stepwise procedure (Statistical Analysis System, version 8.2) between variables of chemical composition of the forage apparently consumed and pasture characteristics that make up the study of Ferreira et al. (2011).

The general model regarding the analysis of the variables studied was represented by: $\mathrm{Yikj}=\mu+\mathrm{Bj}+\mathrm{Ti}+\mathrm{Pk}+\mathrm{TPik}$ + Eij, where: $Y i k j=$ dependent variables, $\mu=$ mean of all observations, $\mathrm{Bj}=$ effect of block $\mathrm{i}, \mathrm{Ti}$ = effect of treatment $\mathrm{i}$ (input levels) $\mathrm{Pk}=$ effect of period $\mathrm{k}$ (seasons); TPik = interaction treatment $\mathrm{i} \times$ period $\mathrm{k}$; Eij $=$ random error associated with each observation $\mathrm{j}$.

\section{Results and Discussion}

As the natural pasture is a complex pastoral environment, where the consumption of nutrients by animals depends not only on the chemical composition of forage, the present study will firstly present the results concerned to the variables that characterize the available forage (Table 2). After Carvalho et al. (2001), the form in which the forage is available to the animal represents its structure and is ultimately responsible for the amount of nutrient intake in grazing.

Sward height and herbage mass were affected by the interaction between seasons and applied inputs (Table 2). There were no significant differences in forage accumulation rate or forage allowances. The average accumulation rate of forage was $21.2 \pm 22.4 \mathrm{~kg} \mathrm{DM} / \mathrm{ha} /$ day and the average forage allowance was $14.6 \pm 4.3 \mathrm{~kg}$ of DM/100 kg body weight.

The sward height on natural pasture without the addition of inputs was lower than the other treatments $(\mathrm{P}<0.05)$ in the summer and the winter (Table 2). In the fall

Table 2 - Effect of input treatments in each season of the year on sward height and forage mass of a natural pasture from southern Brazil

\begin{tabular}{|c|c|c|c|c|}
\hline \multirow[t]{2}{*}{ Treatment $^{1}$} & \multicolumn{4}{|c|}{ Season of the year } \\
\hline & Summer & Fall & Winter & Spring \\
\hline \multicolumn{5}{|c|}{ Sward height $(\mathrm{cm})^{2}$} \\
\hline NP & $10.8 \mathrm{Ba}$ & $7.9 \mathrm{Bb}$ & $8.4 \mathrm{Bb}$ & $7.5 \mathrm{Bb}$ \\
\hline FNP & $14.8 \mathrm{Aa}$ & $9.8 \mathrm{Ab}$ & $11.7 \mathrm{Ab}$ & $10.4 \mathrm{Ab}$ \\
\hline INP & 14.1Aa & $7.7 \mathrm{Bc}$ & $10.8 \mathrm{Ab}$ & $8.3 \mathrm{Bc}$ \\
\hline Mean & 13.2 & 8.5 & 10.3 & 8.7 \\
\hline \multicolumn{5}{|c|}{ Forage mass (kg DM/ha) ${ }^{3}$} \\
\hline NP & 2006.5Ba & 1427.9Ab & 1023.1Bb & $1143.7 \mathrm{Bb}$ \\
\hline FNP & 2656.1Aa & 1542.2Ab & $1303.3 \mathrm{Ab}$ & $1487.0 \mathrm{Ab}$ \\
\hline INP & 2409.0Aa & 1144.1Bb & $1210.4 \mathrm{ABb}$ & $1407.0 \mathrm{Ab}$ \\
\hline$\underline{\text { Mean }}$ & 2357.2 & 1371.4 & 1345.9 & 1178.9 \\
\hline
\end{tabular}

R. Bras. Zootec., v.41, n.6, p.1360-1368, 2012 
and spring, sward height in this treatment was only lower than fertilized natural pasture. Between seasons, the sward height was higher in the summer in all treatments.

The average forage mass of natural pasture was lower than the other treatments $(\mathrm{P}<0.05)$ during the spring and summer, but in the winter, it was only inferior to natural pasture fertilized. Between seasons, herbage mass was higher in the summer in all treatments (Table 2).

The sward height was positively correlated with forage mass $(r=0.81, P<0.0001)$. This correlation was also observed by other authors (Canto et al., 2001; Santos et al., 2004) but it is important to consider, when interpreting these results, that an equal height in different pastures or the same pasture at different times can have different forage masses, especially in plurispecific pastures where one needs to consider besides the density of forage, the floristic composition.

Evaluating the effect of the structure of natural pasture in the intake process of beef calves, Gonçalves et al. (2009) observed that the longer and more sparse leaf blades in the upper strata of the pasture cause more time in form and manipulating the bite hence affecting the bite rate and the ingestion rate. The authors observed that after a height of $11.4 \mathrm{~cm}$, the depth of the bites of calves in natural pasture was not able to compensate the low density of grass blades and dispersion of the uppermost strata. According to the authors, the animals took advantage of the ability to expand their bite area through the movements of the tongue that gives the capture of more forage (Demment \& Laca, 1993). Thus, it appears that the structure of natural pasture in the present study was above the ideal only in the summer in the treatments that received inputs (Table 2), demonstrating a framework for optimization of the intake in the other seasons.

In spite of the differences in the physical variables of the pastures, there was no interaction $(\mathrm{P}>0.05)$ between levels of inputs applied to natural pasture and seasons for the variables related to the chemical composition of the forage apparently consumed by animals. This reinforces the assertion that the sward structure (height/forage mass) was able to optimize the intake process. This also indicates that possibly, the sampling method adequately simulated the selectivity of the diet of animals.

The mean values for ether extract and acid detergent lignin were $23 \pm 4$ and $71 \pm 16 \mathrm{~g} / \mathrm{kg} \mathrm{DM}$, respectively, without effect neither as function of applied inputs nor seasons. High lignin contents and ether extract in the diet can result in a decrease in digestibility of the fiber fraction (Minson, 1990). In the case of ether extract, this decrease is because the lipids form layers on the contact surface of the fibers, preventing the attack of larger organisms
(Vasconcelos, 1997). The values observed for ether extract are within acceptable limits for the diet of ruminants, as proposed by Van Soest (1994) who stated that the maximum content in the diet must be between $50-60 \mathrm{~g} / \mathrm{kg} \mathrm{DM}$. Acceptable values for lignin in diet for ruminants are not proposed in the literature. However, studies from Jung \& Deetz (1993) demonstrate a high negative correlation between lignin content and digestibility of grasses. According to the authors, between the chemical components associated with the cell wall, lignin is one that admittedly limits digestion of cell wall polysaccharides in the rumen. However, diet composition varied in other chemical components between seasons (Table 3).

Although they are required in small quantities by animals, minerals play a key role in the metabolism of all other nutrients (carbohydrates, lipids and proteins) and are especially important in energy metabolism. In addition, they play a role in growth and development of plants. However, this study will only present (Table 3 ) the content of mineral matter by being part of the estimated chemical composition of other fractions, but not discussed in view of the controversies in the literature about its relevance.

For Santos et al. (2007), it is essential to know the mineral matter content of the forage used, to avoid mineral deficiency in the herd and unnecessary expenses with mineral supplementation. These authors observed a reduction of ash content in the hay of two cultivars of Pennisetum purpureum Schum. (elephant grass) with increasing age cutoff from 28 to 112 days the Green cultivar decreased from 184 to 79 g/kg DM and Roxo reduced from 223 to $104 \mathrm{~g} / \mathrm{kg}$ DM content of mineral matter.

However, Silva \& Queiroz (2002) argued that the determination of ash gives only an indication of the richness in calcium and phosphorus in the analysis of feed, when it comes to products like bone meal and products of marine

Table 3 - Average values of different chemical components of the forage apparently consumed by the steers in each season of the year

\begin{tabular}{lccccc}
\hline $\begin{array}{l}\text { Chemical } \\
\text { component }\end{array}$ & \multicolumn{5}{c}{ Season of the year } \\
\cline { 2 - 6 } & Summer & Fall & Winter & Spring & P value \\
\hline MM (g/kg DM) & $91 \mathrm{~B}$ & $100 \mathrm{AB}$ & $120 \mathrm{~A}$ & $95 \mathrm{~B}$ & 0.0081 \\
OM $(\mathrm{g} / \mathrm{kg} \mathrm{DM})$ & $845 \mathrm{~A}$ & $832 \mathrm{~A}$ & $801 \mathrm{~B}$ & $855 \mathrm{~A}$ & 0.0027 \\
$\mathrm{CP}(\mathrm{g} / \mathrm{kg} \mathrm{DM})$ & $101 \mathrm{C}$ & $137 \mathrm{~B}$ & $169 \mathrm{~A}$ & $179 \mathrm{~A}$ & 0.0006 \\
NDIP $(\mathrm{g} / \mathrm{kg} \mathrm{TN})$ & $63 \mathrm{~B}$ & $82 \mathrm{~A}$ & $87 \mathrm{~A}$ & $82 \mathrm{~A}$ & 0.0041 \\
NDFap $(\mathrm{g} / \mathrm{kg} \mathrm{DM})$ & $657 \mathrm{~A}$ & $630 \mathrm{~A}$ & $474 \mathrm{C}$ & $534 \mathrm{~B}$ & $<0.0001$ \\
$\mathrm{ADF}(\mathrm{g} / \mathrm{kg} \mathrm{DM})$ & $414 \mathrm{~A}$ & $398 \mathrm{AB}$ & $322 \mathrm{~B}$ & $339 \mathrm{AB}$ & 0.0160 \\
NFC $(\mathrm{g} / \mathrm{kg} \mathrm{DM})$ & $130 \mathrm{C}$ & $109 \mathrm{C}$ & $210 \mathrm{~A}$ & $169 \mathrm{~B}$ & 0.0003 \\
NDF:NFC ratio & $6.6 \mathrm{~A}$ & $7.1 \mathrm{~A}$ & $2.4 \mathrm{~B}$ & $3.2 \mathrm{AB}$ & 0.0071 \\
\hline
\end{tabular}

Means followed by same letters in the row are not different by Pdiff test $(\mathrm{P}<0.05)$ MM - mineral matter; OM - organic matter; CP - crude protein; NDIP - in neutral detergent insoluble protein; NDFap - neutral detergent fiber corrected for ash and protein; ADF - acid detergent fiber; NFC - non-fibrous carbohydrates. 
origin. Meanwhile, when analyzing vegetable products (forage, diets, grains, etc.), the determination of mineral matter has relatively little value. As mineral components vary widely in vegetable products, the authors claim that the content of mineral matter is not a precise indication of the presence of minerals. Another relevant issue is reported by Fischer et al. (2005), who found, in mid-September to November, high levels of mineral matter in natural pasture (322 and $148 \mathrm{~g} / \mathrm{kg} \mathrm{DM}$ ), assigning these values to the contamination of samples after flooding of the area and subsequent deposition of dried mud on the forage.

According to Alves et al. (2008) the inorganic minerals include macro and trace minerals, while the organic matter is composed of carbon, hydrogen, oxygen, and in some cases, nitrogen. Garcia et al. (2004) found that the OM content of Brachiaria decumbens showed cubic behavior as a function of sampling date, justified by the reduced concentration of potentially digestible components as the plant matures (Euclides, 2000). This study found the opposite, with the lowest OM content (Table 3) observed in the winter. However, in this season there is greater participation of introduced winter species in the improved natural pasture or native winter species in the fertilized natural pasture, i.e., young and tender plants that contribute positively to the chemical composition of the forage. From this result, where the values of OM content promote difference between DM and mineral matter, one can infer that the levels of ash (mineral matter) may disguise the OM levels during the rainy season, when forage may have been contaminated by the soil in swampy areas.

The lower content of CP in the summer was due to the final cycle of C3 species from the natural grassland and the occurrence of rainfall deficiency that retard the regrowth of C4 species. This nutritional value is associated with low levels of crude protein and minerals, the high fiber content and low dry matter digestibility (Table 3). In the following seasons, the CP content increases as function of rainfall that provides high accumulation rate of forage, especially of the winter species. Silveira et al. (2005) observed similar progression of CP content on natural pastures over basaltic soils in the same region of the present assay.

Just as CP increased, there was also increase in the protein bound to the fiber (NDIP) after the summer. About $65 \%$ of the CP content in the summer and fall was associated with the fiber; while in winter and spring the percentage was lower (49\%). The most likely would be the opposite, because the values of fiber (NDFap and ADF) were lower in the last two seasons, and as the fiber content of the plant increases, more protein should be retained in the cell wall. According to Paulino et al. (2002) much crude protein is in insoluble form, which is of slow availability to the animal. Another part of the CP was unavailable for the animal to be bound to acid detergent fiber (ADF), which is the least digestible portion of the cell wall of forages by rumen microorganisms, composed almost entirely of lignocellulose (Silva \& Queiroz, 2002). In this study, this fraction of CP unavailable to the animal (ADIP) showed an average content of $35 \pm 7 \mathrm{~g} / \mathrm{kg} \mathrm{DM}$ $(\mathrm{P}>0.05)$.There is no indication of ideal values of ADIP, but it is usually between $40-70 \mathrm{~g} / \mathrm{kg}$ DM. Fischer et al. (2005) observed, during the spring in natural pasture improved with Lotus subbiflorus and invaded by Eragrostis plana, in southern Rio Grande do Sul, CP and ADF at concentrations similar to the present study in the same season: $175 \mathrm{~g} / \mathrm{kg}$ DM and $358 \mathrm{~g} / \mathrm{kg}$ DM, respectively.

The NDF content is an important parameter that defines the quality of forage and that limits the intake capacity of the animals. The NDF represents the chemical fraction of forage which correlates more closely with the voluntary consumption of animals, and values above 550 to $600 \mathrm{~g} / \mathrm{kg}$ DM correlate negatively (Van Soest, 1965). In this study, except for the winter and spring, the NDF values were above the critical value of $550 \mathrm{~g} / \mathrm{kg} \mathrm{DM}$, considering that these values are free of ash and protein, so the voluntary intake of forages could be limited in case of low supply of forage, which would reduce the selectivity of cattle. But the values of herbage allowance were not restrictive on the use of animals, with mean values of $15.6,13.7,13.5,15.8 \mathrm{~kg}$ of DM/100 kg of body weight (BW) in the summer, fall, winter and spring, respectively. Mannetje et al. (1976) states that the maximum intake per animal is reached when it has about four to five times more than it can consume daily at its disposal, i.e., if the ability of consumption is $2.5 \%$ of the $\mathrm{BW}$, the animal must have 10 to $13 \mathrm{~kg}$ DM/100 kg live weight at its disposal. Assessing the response of natural grassland under different levels of herbage allowance, Moojen \& Maraschin (2002) pointed out that forage allowances around $12 \mathrm{~kg} D M / 100 \mathrm{~kg}$ live weight provide the enhancement of plant and animal production simultaneously.

Plant carbohydrates can be classified as non-fibrous carbohydrates and fibrous carbohydrates. According to Cabral et al. (2000), the former include polymers that comprise the plant cell wall, which, along with lignin, play a role in plant support and protection. These fibrous carbohydrates are represented primarily by the cellulose and hemicellulose, which are available slowly and partially taking up space in the gastrointestinal tract. The nonfibrous carbohydrates, represented by water-soluble sugars (mono-and disaccharides), starch and pectin, are rapidly and completely digested in the gastrointestinal tract (Mertens, 1987; Mertens, 1996). The non-fibrous 
carbohydrates did not differ between the summer and fall, when the lowest levels are observed (Table 3). The higher carbohydrate content of rapid degradation occurred in the winter, decreasing in the spring. This result demonstrated the contribution of native and introduced winter species especially during the winter. The behavior in the spring can be explained, according to Wilson (1994), by increased maturity, which, mainly in summer grasses, involves the increased synthesis of cell wall constituents, as well as its thickening and deposition of lignin, which tends to increase the indigestible fraction, thereby reducing the potentially digestible fraction.

Considering the values of non-fibrous carbohydrates (NFC) and the NDF:NFC ratio (Table 3), it was observed that apparently consumed forage was more digestible in the winter and in spring. From a nutritional standpoint, it is interesting to note the NDF:NFC ratio of natural pastures, because the lower the ratio the better the forage quality, since diets of high NDF:NFC ratio are mostly of low digestibility and vice versa.

Of the chemical compounds tested, only the concentration of neutral detergent fiber corrected for ash and protein (NDFap) and the content of minerals were significantly different as result of inputs application. The NDFap content observed in natural pasture was higher ( $596 \mathrm{~g} / \mathrm{kg}$ DM) but did not differ from the value in fertilized pasture (572 g/kg DM), which, in turn, did not differ from treatment with fertilization and introduction of cultivated winter species (553 g/kg DM).

By studying animal production in natural pasture improved with the introduction of Lolium multiflorum Lam, Trifolium pratense L. and Lotus corniculatus L. on rotational grazing, Brum et al. (2008) found average levels of NDF without correction for ash and protein of 679, 714 and $715 \mathrm{~g} / \mathrm{kg}$ DM, respectively. As in the present study, but taking into account that the samples were cut at soil level (representing the total available forage), these authors found lower NDF content in the treatment where there was the introduction of winter species. One can conclude, therefore, that this type of intervention can provide better utilization of natural pasture. The determination of the NDF fraction of native pasture is important because this parameter can be used to predict forage intake by animals (Dias, 1998), particularly in pastoral production systems, where the mechanism of feed intake control occurs by physical limitations, i.e., the capacity of distension of the rumen (Van Soest, 1994). There was an interaction between season and treatment for in vitro digestibility of organic matter and total digestible nutrients (Table 4).
Table 4 - Interaction between natural pasture treatment and season of the year on the in vitro digestibility of organic matter and on total digestible nutrients

\begin{tabular}{lcccc}
\hline Pasture treatment & \multicolumn{4}{c}{ Season of the year } \\
\cline { 2 - 5 } & Summer & Fall & Winter & Spring \\
\hline \multirow{4}{*}{ Organic matter } & in vitro & digestibility & $(\mathrm{g} / \mathrm{kg} \mathrm{DM})^{1}$ \\
FNP & $507 \mathrm{Aa}$ & $527 \mathrm{Aa}$ & $532 \mathrm{Ba}$ & $539 \mathrm{Ba}$ \\
INP & $510 \mathrm{Ab}$ & $503 \mathrm{Ab}$ & $594 \mathrm{Aa}$ & $569 \mathrm{ABa}$ \\
& $488 \mathrm{Ab}$ & $541 \mathrm{Ab}$ & $617 \mathrm{Aa}$ & $593 \mathrm{Aa}$ \\
NP & Total & digestible & nutrients $(\mathrm{g} / \mathrm{kg}$ & $\mathrm{DM})^{2}$ \\
FNP & $751 \mathrm{Bb}$ & $701 \mathrm{Ab}$ & $774 \mathrm{Bab}$ & $882 \mathrm{Aa}$ \\
INP & $741 \mathrm{Bb}$ & $723 \mathrm{Ab}$ & $988 \mathrm{Aa}$ & $881 \mathrm{Aa}$ \\
\hline
\end{tabular}

${ }^{1} \mathrm{P}=0.0129 ;{ }^{2} \mathrm{P}=0.0322$

Means followed by the same uppercase letter in the column and the same lowercase letter in the rows are not different by Pdiff test at $5 \%$ probability.

NP - natural pasture; FNP - fertilized natural pasture; INP - improved natural pasture.

The deployment of the interaction shows that the apparent digestibility of forage consumed by calves during winter and spring was higher in treatments with inputs. The higher digestibility of the forage in the improved natural pasture in these seasons was due to the contribution of the native species Andropogon lateralis Nees, Stipa setigera Presl, Piptochaetium stipoides (Trin. \& Ruprecht.) Hackel var. stipoides, Paspalum notatum Alain, Mnesithea selloana (Hack.) Sosef \& Koning, Briza subaristata Lam, Paspalum dilatatum Poir. and the exotic winter species Lolium multiflorum Lam (Elejalde, 2011) in this period. The lowest levels of digestibility in the summer also are addressed in the floristic composition of vegetation, mainly due to the phenological stage of plants, because during the summer many species are blooming. According to Heringer \& Jacques (2002), in the winter, summer and winter species are in vegetative stage, while in the summer the species have flourished or are in different degrees of maturity, losing quality.

Moojen \& Maraschin (2002) observed that crude protein and in vitro organic matter digestibility decreased linearly with increasing levels of herbage allowance on natural pasture, which was attributed to the advance in the plant developmental stage. One must consider that the samples of forage for the chemical analysis came from cutting at ground level, so its low CP and in vitro organic matter digestibility, 75 and $400 \mathrm{~g} / \mathrm{kg} \mathrm{DM}$, respectively, cannot be linked to the diet of animals. In this study, the samples were taken simulating the diet selected by the animals. As they preferentially eat young leaves, the mean values are higher than those observed in the study mentioned: 144 and $543 \mathrm{~g} / \mathrm{kg}$ DM of crude protein and in vitro organic matter digestibility, respectively. Using only the green parts of the forage cut at ground level, Coelho Filho \& Quadros (1995), observed 
in natural pasture improved with the introduction of winter species, average values of 133 and $667 \mathrm{~g} / \mathrm{kg}$ DM of crude protein and in vitro organic matter digestibility, respectively.

The content of TDN apparently consumed in each season was different between treatments only during the summer and winter. In the summer, the TDN value of treatment with fertilization and introduction of winter species was greater than the others. In the winter, instead of treatment, forage apparently consumed had higher levels of TDN, but in the treatments with inputs, the animals consumed higher levels of TDN compared with the control. In the fall and spring, there was no difference between treatments; the fall was the season that had lowest values, while in the spring, intermediate values were observed. Under normal feeding conditions, energy is the nutrient that most limits the performance of ruminant animals, requiring special attention from nutritionists regarding the requirements for the animal and its availability in feeds. In Brazil, the TDN has been the most commonly used form of expression in ruminant nutrition; however, the use of animals for in vivo determination of TDN is considered an expensive procedure, which requires time, labor and specific infrastructure (Alves et al., 2008). In this study, as in most studies, estimates of the energy value of feeds were obtained from the chemical and bromatological characteristics of the feed (Cappelle et al., 2001).

The TDN was positively correlated with the in vitro digestibility of organic matter $(\mathrm{r}=0.64, \mathrm{P}<0.0001)$ and negative correlations with NDF corrected for ash and protein $(r=-0.82$, $\mathrm{P}<0.0001)$ and $\operatorname{ADF}(\mathrm{r}=-0.76, \mathrm{P}<0.0001)$. This result was similar to that observed by Cappelle et al. (2001), who found that the level of TDN increased as a function of increased organic matter digestibility, and reduced with elevated levels of acid detergent fiber and neutral detergent fiber.

High temperatures in the summer and fall (Table 1) must have influenced the chemical composition of forage available, so the animals probably reduce intake, in order to save energy in the search and selection of feed. According to the NRC (2000), for every degree below or above $20^{\circ} \mathrm{C}$ there is an increase or a decrease of $0.91 \%$ in the basic animal requirements, so when the ambient temperature increases above the effective thermo-neutral zone, productivity decreases. First, as a result of the decrease in feed intake and, second, due to the increase in the metabolic rate of the animal and work to dissipate heat (respiration rate and heart rate), thereby increasing the energy requirements for maintenance.

Variables related to animal performance in this study, were addressed by Ferreira et al. (2011), who found through multiple regression analysis that $61 \%$ of the daily weight animal gain was explained by the physical characteristics of the pasture (dry matter content, herbage mass, accumulation rate and height of the grass), demonstrating the importance of measuring these parameters in the pasture grazing trials. In order to complement the results of the cited author multiple regressions analysis were performed (Table 5), adding, besides the pasture features, the chemical composition of the forage apparently consumed to see which variables best explain the animal average daily gain (ADG). The set of the added variables NDFap, TDN:CP ratio, in vitro organic matter digestibility and DM explained $80 \%$ of average daily gain. In relation to the characteristics of the pasture that were part of the model presented by Ferreira et al. (2011), had just entered the forage acumulation rate model, but it ended up out due to the entry of other variables. The regression model showed that the average daily gain was more linked to the chemical composition of the forage apparently consumed by the animals than the physical characteristics of the pasture.

There was no interaction between the use of inputs and seasons, in comparison with the TDN:CP ratio, as there was no effect of the use of inputs. During the summer, there was a deficit of $\mathrm{CP}$, while in the other seasons, deficit was energetic. The protein deficit in the summer is evidenced by the lower average daily gain in this season (Table 5).

According to Moore \& Kunkle (1998) the TDN:CP ratio can provide important information about the balance of the diet. These authors hypothesized that when this ratio is above seven, there would be protein deficiency in relation to energy. In these cases, small amounts of protein would allow increased forage intake and consequently better animal performance. However, when this value is below

Table 5 - Variables selected by the regression model for average daily gain $\times$ pasture characteristics $\times$ chemical composition of the forage and seasonal average daily gain of the steers on natural pasture ${ }^{1}$

\begin{tabular}{lccr}
\hline Variables & $\mathrm{R}^{2}$ partial & $\mathrm{R}^{2}$ model & $\mathrm{P}$ value \\
\cline { 2 - 4 } & \multicolumn{4}{c}{ Average daily gain (ADG) } \\
\hline NDFap & 0.49 & 0.49 & $<0.0001$ \\
TDN:CP & 0.16 & 0.66 & 0.0004 \\
OMIVD & 0.04 & 0.771 & 0.0106 \\
DM & 0.03 & 0.80 & 0.0341
\end{tabular}

Variable

Summer Fall Winter Spring

$\begin{array}{lllll}\mathrm{TDN}: \mathrm{CP}^{2} & 7.8 \mathrm{~A} & 5.3 \mathrm{~B} & 5.4 \mathrm{~B} & 5.1 \mathrm{~B}\end{array}$

$\mathrm{ADG}^{3}$ (kg/animal/day) $\quad 0.16 \mathrm{C} \quad 0.87 \mathrm{~B} \quad 1.26 \mathrm{~A} \quad 0.78 \mathrm{~B}$

${ }^{1}$ The difference in the sum of $\mathrm{R}^{2}$ of the model is due to the discard of the variable "forage accumulation rate" at this point.

${ }^{2} \mathrm{P}<0.0001 ;{ }^{3} \mathrm{P}<0.0001$.

Regression model: ADG $=17.237-0.1052$ DM -0.0430 NDFap -0.054 OMIVD - 0.2086 TDN:CP.

NDFap - neutral detergent fiber corrected for ash and protein; TDN - total digestible nutrients; CP - crude protein; OMIVD - organic matter in vitro digestibility; DM - dry matter; ADG - average daily gain. 
seven, the energy can limit animal performance, requiring supplementation for better performance. It is noteworthy that not always does a relationship equal to seven indicate quality, which demonstrates that both nutrients are scarce. The supply of energy supplementation could not per se eliminate energy and protein deficiencies, because the latter does not fully address. However, according to Paulino et al. (1982), both the deficiency in energy and protein can be eliminated only by correcting the protein deficiency. In this study, the protein deficiency in the summer would be solved by lowering the height of the pasture (Table 2) to $11.4 \mathrm{~cm}$ (Gonçalves et al., 2009), promoting less dispersion in the upper leaf blades and consequently the optimization of the ingestion process in the season. This kind of management would provide a more adequate pasture structure, promoting greater possibility to optimize intake and consequence animal performance, as in the other seasons.

\section{Conclusions}

The botanical diversity of the natural pastures on vertisoils in the Campanha region of south Brazil, when managed with adequate forage allowance, has enough quality to meet their nutritional requirements for steers in the finishing phase. The use of inputs such as fertilizers and cultivated winter species enables changes in the potentially degradable fiber of the natural grassland that are desirable for animal production. The seasons have a marked influence on the chemical composition of the forage apparently consumed by animals. Fertilization may help to stabilize the quality of fodder throughout the year, particularly through its effect on the participation of winter species, providing an increase in some fractions of the chemical composition of forage in this season. The chemical composition of the diet selected is the determining factor for the weight gain of animals on natural pasture.

\section{Acknowledgments}

To CNPq and Cantagalo Farm for financing this experiment and to the owners and employees of the Cantagalo Farm for their affectionate welcoming.

\section{References}

ALVES, A.A.; MOREIRA FILHO, M.A.; SILVA, D.C. et al. Avaliação de alimentos para ruminantes no nordeste do Brasil. In: CONGRESSO BRASILEIRO DE NUTRIÇÃO ANIMAL, 1., 2008, Fortaleza. Anais... Fortaleza: CBNA, 2008. (CD-ROM).

ASSOCIATION OF OFFICIAL ANALYTICAL CHEMISTS - AOAC. Official methods of analysis. 16.ed. Washington, D.C.: 1995. 1015p.
BARTHRAM, G.T. Experimental techniques: the HFRO sward stick. Midlothian: Hill Farming Research Organization, 1985. p.29-30. (Biennial Report).

BRUM, M.S.; QUADROS, F.L.F.; MATINS, J.D. et al. Sistemas de alimentação para recria de ovinos a pasto: avaliação do desempenho animal e características da forragem. Revista Ciência Rural, v.8, n.1, p.191-198, 2008.

CABRAL, L.S.; VALADARES FILHO, S.C.; MALAFAIA, P.A.M et al. Frações de carboidratos de alimentos volumosos e suas taxas de degradação estimadas pela técnica de produção de gases. Revista Brasileira de Zootecnia, v.29, n.6, p.2087-2098, 2000.

CANTO, M.W.; CECATO, U.; PETERNELLI, M. et al. Efeito da altura do capim-tanzânia diferido nas características da pastagem no período do inverno. Revista Brasileira de Zootecnia, v.30, n.4, p.1186-1193, 2001.

CAPPELLE, E.R.; VALADARES FILHO, S.C.; SILVA, J.F.C. et al. Estimativas do valor energético a partir de características químicas e bromatológicas dos alimentos. Revista Brasileira de Zootecnia, v.30, n.6, p.1837-1856, 2001.

CARVALHO, P.C.F.; RIBEIRO FILHO, H.M.N.; POLI, C.H.E.C et al. Importância da estrutura da pastagem na ingestão e seleção de dietas pelo animal em pastejo. In: REUNIÃO ANUAL DA SOCIEDADE BRASILEIRA DE ZOOTECNIA, 38., 2001, Piracicaba. Anais... Piracicaba, 2001, v.1, p.853-871.

COELHO FILHO, R.C.; QUADROS, F.L.F. Produção animal em misturas forrageiras de estação fria semeadas em uma pastagem natural. Ciência Rural, v.25, n.2, p.289-293, 1995.

DEMMENT, M.W.; LACA, E.A. The grazing ruminant: Models and experimental tecniques to relate sward structure and intake. In : WORLD CONFERENCE ON ANIMAL PRODUCTION, 7. 1993, Edmonton. Proceedings... Edmonton, 1993. p.439- 460.

DETMANN, E.; VALADARES FILHO, S.C.; PINA, D.S. et al. Prediction of the energy value of cattle diets based on the chemical composition of the feeds under tropical conditions. Animal Feed Science and Technology, v.143, p.127-147, 2008a.

DETMANN, E.; MAGALHÃES, K.A.; VALADARES FILHO, S.C. et al. Desenvolvimento de um sub-modelo bi-compartimental para estimação da fração digestível da proteína bruta em bovinos a partir da composição química dos alimentos. Revista Brasileira de Zootecnia, v.37, n.12, p.2215-2221, 2008b.

DIAS, A.E.A. Caracterização da qualidade nutricional da pastagem natural da região agroecológica Serra do Sudeste - RS. 1998. 152f. Dissertação (Mestrado em Zootecnia) Universidade Federal de Pelotas, Pelotas.

ELEJALDE, D.A.G. Interface palnta-animal em função da intensidade de aplicação de insumos em pastagem natural 2011. 159f. Tese (Doutorado em Zootecnia) - Programa de Pós-Graduação em Zootecnia, Faculdade de Agronomia, Universidade Federal do Rio Grande do Sul, Porto Alegre.

EMPRESA BRASILEIRA DE PESQUISA AGROPECUÁRIA EMBRAPA. Centro Nacional de Pesquisa do Solo. Sistema brasileiro de classificação de solos. 2.ed. Rio de Janeiro: Embrapa Solos, 2006. 306p.

EUCLIDES, V.P.B. Intensificação da produção de carne bovina em pastagem. Curso de suplementação em pasto e confinamento de bovinos. 2000. Available at: <http://www.cnpgc. embrapa.br/ publicacoes/naoseriadas/cursosuplementacao/manejo> Accessed on: Nov. 13, 2010.

FERREIRA, E.T.; NABINGER, C.; ELEJALDE, D.A.G. et al. Fertilization and oversowing on natural grassland: effects on pasture characteristics and yearling steers performance. Revista Brasileira de Zootecnia, v.40, n.9, p.2039-2047, 2011.

FISCHER, V.; PARDO, R.M.P.; ZANELA, M.B. et al. Ganho de peso de novilhos mantidos em pastagem natural na encosta do sudeste do rio grande do sul, recebendo níveis crescentes de suplementação energética. Revista Brasileira de Zootecnia, v.34, n.1, p.159-166, 2005. 
GARCIA, J.; ALCALDE, C.R.; ZAMBOM, M.A. et al. Desempenho de novilhos em crescimento em pastagem de Brachiaria decumbens suplementados com diferentes fontes energéticas no período da seca e transição seca-águas. Revista Brasileira de Zootecnia, v.33, n.6, p.2140-2150, 2004.

GONÇALVES, E.N.; CARVALHO, P.C.F.; KUNRATH, T.R. et al. Relações planta-animal em ambiente pastoral heterogêneo: processo de ingestão de forragem. Revista Brasileira de Zootecnia, v.38, p.1655-1662, 2009.

HAYDOCK, K.P.; SHAW, N.H. The comparative yield method for estimating dry matter yield of pasture. Australian Journal of Agriculture and Animal Husbandry, v.15, p.66-70, 1975.

HERINGER, I.; JACQUES, A.V.A. Qualidade da forragem de pastagem nativa sob distintas alternativas de manejo. Pesquisa Agropecuária Brasileira, v.37, n.3, p.399-406, 2002.

JUNG, H.G.; DEETZ, D.A. Cell wall lignification and digestibility. In: JUNG, H.G.; BUXTON, D.R.; HATFIELD, R.D. et al. (Eds.) Forage cell wall structure and digestibility. Madison: ASA/ CSSA/SSSA, 1993. p.315-346.

KLINGMANN, D.L.; MILES, S.R.; MOTT, G.O. The cage method for determining consumption and yield of pasture herbage. Journal of Society Agronomy, v.35, p.739-746, 1943.

LICITRA, G.; HERNANDEZ, T.M.; VAN SOEST, P.J. Standardization of procedures for nitrogen fractionation of ruminant feeds. Animal Feed Science and Technology, v.57, p.347-358, 1996

LITTEL, R.C.; MILLIKEN, G.A.; STROUP, W.W. et al. SAS system for mixed models. Cary: SAS Institute, 1996. 633p.

MANNETJE, L.T'.; JONES, R.J.; STOBBS, T.H. Pasture evaluation by grazing experiments. In: SHAW, N.H.; BRYAN, W.N. (Eds.) Tropical pasture research. Farnham Royal: Commonwealth Agriculture Bureaux, 1976. p.194-234.

MARASCHIN, G.E. Production potential of South American grasslands. In: INTERNATIONAL GRASSLAND CONGRESS, 19., 2001, São Pedro. Proceedings... São Pedro: ESALQ, 2001. p.5-15.

MAURICIO, R.M.; MOULD, F.L.; DHANOA, M.S. et al. A semiautomated in vitro gas production technique for ruminants fedstuff evaluation. Animal Feed Science and Technology, v.79, p.321-330, 1999.

MERTENS, D.R. 1987. Predicting intake and digestibility using mathematical models of ruminal function. Journal Animal Science, v.64, n.5, p.1548-1558

MERTENS, D.R. Using fiber and carbohydrate analyses to formulate dairy rations. In: INFORMATIONAL CONFERENCE WITH DAIRY AND FORAGES INDUSTRIES, 1996, Wisconsin. Proceedings... Wisconsin, 1996. p.81-92.

MINSON, D.J. Forage in ruminant nutrition. San Diego: Academic Press, 1990. 483p.

MINSON, J.G. Influence of sward characteristics on diet selection and herbage intake by the grazing animal. In: HACKER, J.B. (Ed). Nutritional limits to animal production from pastures. Farnham Royal: CSIRO, 1982. p.169-174.

MOOJEN, E.L.; MARASCHIN, G.E. Potencial produtivo de uma pastagem nativa do rio grande do sul submetida a níveis de oferta de forragem. Ciência Rural, v.32, n.1, p.127-132, 2002.

MOORE, J.E.; KUNKLE, W.E. Balancing protein and energy in forages. In: FLORIDA BEEF CATTLE SHORT COURSE, 1998, Gainesville. Proceedings... Gainesville: University of Florida, 1998. p.126.

MORAES, E.H.B.K.; PAULINO, M.F.; ZERVOUDAKIS, J.T. et al. Avaliação qualitativa da pastagem diferida de Brachiaria decumbens Stapf., sob pastejo, no período da seca, por intermédio de três métodos de amostragem. Revista Brasileira de Zootecnia, v.34, n.1, p.30-35, 2005.
MOTT, G.O.; LUCAS, H.L. The design, conduct and interpretation of grazing trials in cultivated and improved pastures. In: INTERNATIONAL GRASSLAND CONGRESS, 6., 1952, Pennsylvania. Proceedings... Pennsylvania: State College, 1952. p.1380-1385

NABINGER, C.; FERREIRA, E.T.; FREITAS, A.K. et al. Produção animal com base no campo nativo: aplicações de resultados de pesquisa. In: PILLAR, V.P.; MÜLLER, S.C.; CASTILHOS, Z.M.S. et al. (Eds.) Campos Sulinos: conservação e uso sustentável da biodiversidade. Brasília: MMA, 2009. p.175-197.

NATIONAL RESEARCH COUNCIL - NRC. Nutrient requirements of beef cattle. 7.rev.ed. Washington, DC: National Academy Press, 2000. 248p.

PAULINO, M.F.; REHFELD, O.A.M.; RUAS, J.R.M. Alguns aspectos da suplementação de bovinos de corte em regime de pastagem durante a época seca. Informativo Agropecuário, v.8, n.89, p.28-31, 1982

PAULINO, M.F.; ZERVOUDAKIS, J.T.; MORAES, E.H.B.K. et al Bovinocultura de ciclo curto em pastagens. In: SIMPÓSIO DE PRODUÇÃO DE GADO DE CORTE, 3., 2002, Viçosa, MG. Anais... Viçosa, MG: UFV, 2002. p.153-196.

PELL, A.N.; SCHOFIELD, P. Computerized monitoring of gas production to measure forage digestion in vitro. Journal of Dairy Science, v.76, n.4, p.1063-1073, 1993.

RAMBO, B. A fisionomia do Rio Grande do Sul. 3.ed. São Leopoldo: UNISINOS, 1956. 473p.

SANTOS, B.N.R.; SALES, R.O.; COSTA, M.R.G.F. Teores de matéria seca e matéria mineral do feno de duas variedades de capim elefante sob quatro períodos de corte. In: SIMPÓSIO DE NUTRIÇÃO E ALIMENTAÇÃO ANIMAL, 1., 2007, Fortaleza. Anais... Fortaleza: AMVECE, 2007. (CD-ROM).

SANTOS, D.T.; CARVALHO, P.C.F.; FREITAS, F.K. et al. Adubação de pastagem natural no Sul do Brasil. 1. Efeito do nitrogênio sobre a produção primária. In: GRASSLAND ECOPHYSIOLOGY AND GRAZING ECOLOGY, 2., 2004, Curitiba. Proceedings.. Curitiba: UFPR/Macromedia, [2004] (CD-ROM).

SILVA, D.J.; QUEIROZ, A.C. Análise de alimentos: métodos químicos e biológicos. Viçosa, MG: UFV, 2002. 235p.

SILVEIRA, V.C.P.; VARGAS, A.F.C.; OLIVEIRA, J.O.R. et al. Qualidade da pastagem nativa obtida por diferentes métodos de amostragem em diferentes solos na Apa do Ibirapuitã, Brasil. Ciência Rural, v.35, n.3, p.582-588, 2005.

THEODOROU, M.K.; WILLIAMS, B.A.; DHANOA, M.S. et al. A simple gas production method using a pressure transducer to determine the fermentation kinetics of ruminant feeds. Animal Feed Science and Technology, v.48, p.185-197, 1994.

VAN SOEST, P.J. Nutritional ecology of the ruminant. Ithaca: Cornell University Press, 1994. 476p.

VAN SOEST, P.J. Symposium on factors influencing the voluntary intake of herbage by ruminants: voluntary intake relation to chemical composition and digestibility. Journal of Animal Science, v.24, n.3, p.834-844, 1965.

VAN SOEST, P.J.; ROBERTSON, J.B.; LEWIS, B.A. Methods for dietary fiber, neutral detergent fiber, and nonstarch polysaccharides in relation to animal nutrition. Journal of Animal Science, v.74, n.10, p.3583-3597, 1991.

VASCONCELOS, V.R. Caracterização química e degradação de forrageiras do semi-árido brasileiro no rúmen de caprinos. 1997. 132f. Tese (Doutorado em Zootecnia) Faculdade de Ciências Agrárias e Veterinárias/Universidade Estadual Paulista, Jaboticabal.

WILSON, J.R. Cell wall characteristics in relation to forage digestion by ruminants: review. Journal Agriculture Science, v.122, n.2, p.173-182, 1994. 